\title{
SUPPLY CHAIN MANAGEMENT: MODELS FOR PRODUCTIVITY, SUSTAINABILITY AND EFFECTIVE MARKETING
}

Ikechukwu-Maria Nnamdi Hyacinth Okoye (Mr.), University Of Nigeria, Nsukka Center For Entrepreneurship And Development Research/Entrepreneurship Development Center (South East), Onitsha, Nigeria

dx.doi.org/10.18374/EJM-14-1.12

\begin{abstract}
Supply chain management is a strategic business process or approach which has been used in various loose terms to explain or describe the materials management process of an organization. The result of this materials management process influences the productivity of the organization which goes to determine the sustainability of operations as well as their effectively meeting the needs of the organizationsâ€ ${ }^{\mathrm{TM}}$ customers and satisfying the fund ownersâ $\epsilon^{\mathrm{TM}}$ objectives. This conceptual study constructs models which define the relationships of the variables and show how the result of the relationships satisfies the two major actors â $\epsilon^{\prime \prime}$ the customers and the fund owners (otherwise known as corporate objective).
\end{abstract}

Keywords: Supply chain management, productivity, sustainability, effective marketing, customer satisfaction, corporate objective. 